\title{
БОШЛАНҒИЧ СИНФ ЎҚУВЧИЛАРИДА КИТОБХОНЛИК ВОСИТАСИДА БАДИИЙ АДАБИЁТ НАМУНАЛАРИГА ҚИЗИҚИШНИ ШАКЛЛАНТИРИШНИНГ ЎЗИГА ХОС ЖИХАТЛАРИ
}

DOI: $10.53885 /$ edinres.2021.40.32.032

\author{
Б. У. Мингбаева
}

Тошкент давлат педагогика университети ўқитувчиси

Аннотация. Ушбу мақ̧олада бошлангич синф уцқувчиларида китобхонлик воситасида бадиий адабиёт намуналарига құзиқични шакллантиришнинг ўзига хос жихқатлари ёритилган. Шунингдек, маққоладабилишга асосланганқизиқишларшахс фаоллигинитаъминловчи мотив бўлиб, у билиш фаолияти ривожланишига кўмаклашиши хฺақуида фикр юритилган.

Калит суизлар: кичик ёшдаги уукувчилар, китобхонлик, бадиий адабиёт намуналари, құизқ̧ии, ўқув предметлари, хуаётий вазиятлар, динамик ривожлании, интеллектуал ривожланиш, эмоционал фаоллик, уқ̆иш мотивлари, эхутиёж.

Аннотация. В данной статье рассматриваются особенности формирования интереса к образцам художественной литературы через чтение у учашихся начальной школь. Также в статье интерес, основанный на знаниях, является мотивацией, обеспечивающей активность человека, и считается, что познание способствует развитию активности.

Ключевые слова: младшие икольники, чтение, примеры художественной литературы, интерес, учебные предметы, жизненныле ситуации, динамическое развитие, интеллектуальное развитие, эмоциональная активность, мотивация чтения, потребность.

Abstract. This article discusses the features of the formation of interest in the samples of fiction through reading among primary school students. Also in the article, knowledge-based interest is the motivation that ensures human activity, and it is believed that knowledge contributes to the development of activity

Key words: and phrases: primary school students, reading, examples of fiction, interest, academic subjects, life situations, dynamic development, intellectual development, emotional activity, reading motivation, need.

Бугунги кунда шахс имкониятларини кенгайтиришнинг кўплаб йўналишлари ва воситалари мавжуд. Бундай воситалар биринчи 
навбатда хар бир инсоннинг билиш имкониятларини кенгайтиришга хизмат қилади. Китоб ва китобхонликка бўлган қизиқиш шахс фаолиятининг самарали кечишини таъминлайди. Шунинг учун хам китобхонлик воситасида ўкувчиларда бадиий адабиётга нисбатан қизиқишни шакллантириш алохида ахамиятга эга.

Педагогика энциклопедиясида “Қизиқиш - 1) объект ёки ходисани англаш ва бирор фаолият турини ўзлаштиришга мойиллик; 2) ўқувчи ёки талабанинг ўзи учун қимматли ва ёқимли бўлган муайян нарса ва ходисага муносабати" [1; 391-б.] сифатида таъриф берилган.

Қизиқишларда шахснинг ўзига хос хусусиятлари мужассамлашган бўлади. Қизиқиш билимларни онгли, пухта, барқарор, англаган холда ўзлаштиришга кўмаклашади. Қизиқиш инсонда интилиш, фаоллик, ички туртки, эхтиёжни шакллантиришга хизмат қилади. Қизиқиш шахснинг борлиққа танлаб муносабатда бўлиши, ўзига хос қарор қабул қилиши, ўзини ўзи назорат эта билиши, мақсадга интилувчанлигида, юзага келган тўсиқларни енгишида намоён бўлади. Шунинг учун хам ўкувчиларда бошланғич синфлардан бошлаб у ёки бу ходисага нисбатан қизиқиш уйғотиш алохида ахамиятга эга. Қизиқиш туфайли ўқувчилар муйян объектни чуқурроқ ўзлаштиришга интиладилар. У хақидаги билимларни алохида интилиш билан ўзлаштиришга киришадилар.

Бошланғич синф ўқувчиларида бадиий адабиётга қизиқиш уйғотиш орқали инсоният ақл-идрокининг нодир намуналарида ифодаланган билимлар ва хаётий тажрибаларни ўрганишларига кенгроқ шароит яратилади. Ў қувчиларда бадиий адабиётга нисбатан қизиқиш уйғотишда китобхонлик асосий восита сифатида хизмат қилади.

Р.Г.Сафарова[2]нинг фикрича, ўқувчиларда бадиий адабиётга қизиқиш уйғотишда таълим жараёни асосий ўрин эгаллайди. Таълим жараёни олдига шахсни хар томонлама уйғун ривожлантириш вазифаси қўйилган бугунги кунда ўқувчиларда китоблар ёрдамида бадиий адабиётга қизиқиш уйғотиш ижтимоий-педагогик заруриятга айланмоқда. Китоб ўқиш орқали ўқувчилар ўз билимларини мунтазам такомиллаштиришга муваффақ бўладилар. Ахборот технологиялари ва ахборот олиш манбаларининг кўпайганлиги туфайли ўқувчилар китобга тобора камроқ мурожаат қилмокдалар. Ўқувчилар билан ўзаро муносабатга киришишнинг дастлабки кунларидан бошлаб ўқитувчилар уларда бадиий адабиётга нисбатан қизиқиш уйғотишлари лозим. Айнан бошланғич синфларда бадиий адабиётга нисбатан ўқувчиларда шаклланган қизиқишлар барқарор бўлиб, бутун хаёти давомида мустахкамланиб боради.

Ўқувчиларда бадиий адабиётга қизиқиш уйғотиш ғоясининг асосчиси буюк чех педагоги Я.А.Коменский[3] хисобланади. У ўзининг 
“Буюк дидактика” асарида ўқувчиларда у ёки бу машғулотга нисбатан қизиқиш уйғотиш хақида фикр юритган.

Қизиқиш билиш эхтиёжларининг намоён бўлиш шаклидир. У шахсни ўз фаолияти мақсадини англашга йўналтиради. Объектив борлиқни ифодалайдиган далилларнинг мохиятини чуқурроқ англашга ундайди. Қизиқиш шахснинг ўрганилаётган объектни ўзлаштиришга бўлган интилишини ифодалайди. Ўқувчининг айни бир қизиқишини қондириш иккинчи қизиқишнинг вужудга келишига асос бўлиб, билиш фаолиятининг ривожланишига шароит яратади.

Л.С.Выготский[4]нингтаъбирича, қизиқишлар болахулқ-атворининг харакатлантирувчи кучи хисобланади. У ўқувчи интилишларининг ёрқин ифодасидир. Қизиқишлар ёрдамида ўқувчиларнинг фаолияти уларнинг эхтиёжларига мувофиқ келади. Шунинг учун хам таълимтарбия жараёни ўқувчиларнинг қизиқишларига асосланган холда ташкил этилиши керак. Бу ўқув жараёнининг ўқувчиларни қизиқтирган ўкув предметларига устиворлик бериш асосида ташкил этишини англатади. Ўқувчига босим ўтказиш, пўписа қилиш, қўрқитиш орқали уни муайян ходисани ўрганишга жалб этиш мумкин эмас. Ўқувчиларда қизиқиш уйғотиш билан бир қаторда уни муайян мақсадга йўналтириш хам мухим ахамиятга эга.

Мухимжихатларданяна бири ўқувчиларнингқизиқишларинихисобга олган холда ўкув жараёнларини хаётий вазиятларга яқинлаштиришдан иборат. Ўқув жараёнини хаётий вазиятларга яқинлаштиришда бадиий адабиёт намуналари мухим ўрин эгаллайди. Ўқув жараёнини хаётий вазиятларга яқинлаштириш ўқувчиларда муайян ходисаларга нисбатан қизиқиш уйғотади. Педагоглар ўқувчиларда қизиқиш уйғотиш орқали уларни аниқ бир фаолиятга кенгроқ жалб этиш мумкинлигини англаб етишлари лозим.

Хар бир шахс ўзини ўраб турган борлиққа нисбатан шахсий муносабат тажрибасига эга. Худди мана шу муносабат уни муайян вазиятларга олиб киради ва маълум нарсаларни ўрганишга нисбатан қизиқиш, эхтиёж ва истакни вужудга келтиради.

Билишга оид қизиқишлар ўқув жараёнининг динамик ривожланишини таъминлашга кўмаклашади. У ўқувчиларнинг фаол тарзда ўқув-билув фаолиятини ўзлаштиришларига ёрдам беради. Билишга оид қизиқишлар ўқувчиларда ташаббускорликни таркиб топтиради. Бу жараёнда ўқувчининг ўзи янги билимларни ўзлаштириш усулларини излаб топади. Натижада таълим, тарбия ва ривожланишнинг самарадорлиги ортади. Фаол бўлмаган ва хеч нарсага қизиқмайдиган ўкувчиларга ўқитувчилар кучли таъсир ўтказиб, уларнинг билишга оид қизиқишларини муайян мақсадга йўналтиришлари керак. 
Қизиқишлар ўқувчиларда ёрқин хис-туйғуларни вужудга келтириш имкониятига эга. Ў қувчилар ўз қизиқишларини қондириш учун объектив борлиқни чуқурроқ ўрганишлари, унинг ўзига хос жихатларини англаб етишлари талаб қилинади. Ўқувчиларнинг қизиқишлари қондирилиши натижасида уларда қувонч хисси, кўпроқ билишга интилиш майллари кучаяди. Агар ўқувчилар ўзлари қизиққан муайян нарсани ўргана олмасалар уларда салбий хис-туйғулар, ўз кучларига ишонмаслик вужудга келади. Билишга оид қизиқишлар ўқишнинг асосий мотивларидан бири хисобланади. Буни ўқувчилар бошқалардан кўра кўпроқ хис этадилар. Бу ўқувчилар ўзлари учун нима қизиқарлию, нима қизиқарли эмаслигини аниқлаб олган вақтларидан бошланади. Бундай нарсалар сирасига дарс, ўқув предмети ёки муайян китобларни киритиш мумкин.

Ўқувчилар учун билишга оид қизиқишлар ўқиш мотивлари сифатида уларни мазкур объектларни билишга ундайди. Мазкур ўринда ўқитувчилар уларга тўсқинлик қила олмайдилар, чунки бу ўкувчиларнинг шахсий қизиқишлари билан боғлиқ. Бу ўқувчилар фаолиятининг асосий мақсадини ифодалаб, ўқув жараёнининг осон, самарали, ёрқин, хис-туйғуларга бой бўлишини таъминлаб уларнинг дарсларда толиқмасликларига асос яратади. Билишга оид қизиқишлар ўқув фаолиятининг турли майллари билан ўзаро алоқадор бўлиб, ўқувчи дунёқарашини хар томонлама бойитишга кўмаклашади. Ушбу қизиқишлар бир-бирига мос келмаса, ўқувчиларнинг ривожланиш жараёнлари секин кечади. Ўқувчиларда муайян ходисаларга нисбатан қизиқишнинг шаклланиши натижасида уларда ўқув жараёнига нисбатан онгли муносабат хосил бўлади. Бу эса ўз навбатида ўқувчиларнинг ўз шахсий ўқув-билув фаолиятларини бошқаришлари, қўйилган мақсадга эришиш йўллари ва мақсадларини аниқ англаб олишларига кўмаклашади. Шу билан бир қаторда ўзлари қизиққан сохадаги билим, кўникма, малакаларининг мунтазам бойишини таъминлайди.

О.А.Тўрақулова[5]нинг фикрича, ўқувчиларда билишга оид қизиқишларни шакллантириш ўқитувчи зиммасидаги мураккаб вазифалардан хисобланади. Бунинг учун педагог ўқув жараёнини ўкувчиларда билиш қизиқишларини шакллантиришга йўналтирган холда ташкил этиши лозим. Бу жараёнда ўқувчи мунтазам тарзда ўқув материалларига қизиқиши, ўз-ўзини ривожлантириши, ўзлаштирган билимларининг йўналиши ва сохаларини кенгайтириши мақсадга мувофиқ. Ўқувчилар ўқув жараёнида туғилган муаммоларни ечишга ўз шахсий хиссаларини қўшишлари хам мухим ахамиятга эга.

Ушбу мақсадга эришиш учун ўқитувчи педагогик жараёнда вужудга келадиган кўплаб муаммоларни бартараф этиши, дарсни ташкил 
этишнинг энг яхши усулларини танлаши талаб этилади. Бунинг учун ўқитувчи зарур ўқув материалларини танлайди, ўқувчиларда мустақилликни шакллантиришга оид турли ёндашувларни тахлил қилади, таълим мақсадига эришилганлик натижасини аниқлайди.

Ўқувчиларнинг қизиқишларини қондириш нафақат уларнинг интеллектуал сохаларини бойитиш, балки, уларни келажакдаги фаолиятга йўналтириш имкониятига хам эга.

Ўқувчиларнинг билишга оид қизиқишларини ривожлантириш сохасида қуйидаги даражаларни ажратиб кўрсатиш мумкин:

синчковлик

қизиқувчанлик

шахсий билишга асосланган қизиқиш

ижодий қизиқиш.

Улар ўқувчиларнинг у ёки бу ўқув предметига нисбатан турлитуман қизиқишларини ифодалайди. Хали ўрганилмаган билимларни ўрганишга интилиш, янги ахборотларни ўзлаштириш кабилар шулар жумласидандир.

Синчковлик - билишга асосланган қизиқишнинг дастлабки босқичи хисобланади. Бунда ўқувчининг эътибори билан боғлиқ тарзда унинг муайян нарсаларни ўрганишга, билишга бўлган интилиши ифодаланади. Қизиқишнинг ушбу босқичида муайян объект ёки ходиса чуқур ўрганилмайди, балки унга синчковлик билан назар ташланади. Бунда шахс ўзини ўраб турган воқеликда қандай ўзгаришлар рўй берганлигини синчковлик билан ўрганишга киришади ва унга муносиб жавоб қайтаради.

Бу босқичдаги қизиқишлар мунтазам эмас балки, элементар характерга эга бўлиб, асосланмаган вазиятга боғлиқ холда вужудга келади. Бу холат айниқса ўкувчилар мактабга келган дастлабки кунларда кузатилади. Ўқувчилардаги бундай кузатишлар атрофдаги айрим нарсаларга боғлиқ бўлиб, юзаки характер касб этади. 3-4-синф ўқувчилари эса атрофдаги нарсаларга қизиқувчанлик билан муносабатга киришадилар.

Қизиқишнинг қизиқувчанликка асосланган босқичи янгича мохият касб этиб, уни қизиқтирган ходисалар ва нарсаларнинг барча ўзига хос жихатларини аниқлашга бўлган интилиш кучаяди. Ушбу жараёнда билиш мақсадга йўналтирилганлик характерига эга бўлиб, ўқувчиларнинг интилишларига ташқи омиллар таъсир кўрсатади. Қизиқувчанлик босқичида ўқувчиларда бевосита қизиқишга бўлган интилишнинг шаклланганлигини кузатиш мумкин. Бунда ўкувчи билиш жараёнига тўлиқ жалб этилади. Унинг ёрдамида эса ўзининг билиш эхтиёжларини қондиради. Бундай фаолиятнинг натижаси ўқувчи учун алохида ахамият 
касб этади. Натижада ўқувчи ўзи қизиққан сохани чуқурроқ ўрганишга киришади, бир нуқтада тўхтаб қолмайди. Қизиқувчанлик эса шахсий қизиқишга айланади.

Билишга асосланган қизиқиш сабаб-оқибат боғланишларини шакллантириш заруриятини келтириб чиқаради. Натижада ўқувчилар мазкур боғланишнинг ўзига хос хусусиятларини аниқлашга харакат қила бошлайдилар. Ушбу босқичда ўқувчилар олдига муайян муаммолар қўйилади. Ўқувчилар эса ушбу муаммоларга онгли тарзда ечим топишга интиладилар. Билишга асосланган қизиқишлар ўқувчиларни билмасликдан узоқлаштиради. Объектив борлиқнинг янги жихатларини англаш, интеллектуал ривожланишнинг янги босқичларига кўтарилишларини таъминлайди. Натижада ўқувчиларнинг фаол харакатлари таъминланади: ўз-ўзини назорат қилиш, ирода кучига ишониш, иш жараёнида ташаббускорлик ва некбинлик, ўз-ўзини такомиллаштириш ва ривожлантиш истагига эгаликнинг намоён бўлиши.

Ижодий қизиқишларнинг намоён бўлиш босқичи қуйидагиларни ўз ичига олади: мустақиллик, ўқувчининг қайта шаклланган фаолияти, ўз олдиларида турган муаммоларнинг янгича ечимларини таъминловчи усулларни қўллаш, ўз ижодий лаёқатларини намоён қилиш кабилар.

Китобхонликка бўлган қизиқиш - ўқувчиларнинг китобларда ифодаланган аждодлар тажрибасини ўрганиш ва ўз фаолиятида қўллашга бўлган интилишини ифодаловчи қизиқишдир. Бунинг учун ўқувчиларда ақлий хамда эмоционал фаоллик шаклланиши лозим. Ақлий хамда эмоционал фаоллик китобларда мақсадга йўналтирилган асосий компонент сифатида намоён бўлиб, ўқувчиларга ижтимоий тажрибани тақдим этишга хизмат қилади. Чунки китобларда ушбу тажриба сақланиб, аждодлардан авлодларга тақдим этилади. Шунга кўра, билишга асосланган қизиқишлар танловга асосланган қизиқиш бўлиб, биринчи навбатда ўқувчиларнинг интеллектуал сохасини ривожлантиришга кўмаклашади. Қизиқиш ёрдамида ўқувчилар муайян сохадаги билимларни ўзлаштиришга фаол киришадилар. Бунда уларга китоб яқиндан ёрдам беради.

Шахснинг ривожланиши учун билишга оид қизиқишларнинг ахамияти шундаки, унда муайян сохадаги фаолият қизиқиш таъсирида ўкувчининг рухий жараёнларини фаоллаштиради. Ўқувчиларда интеллектуал қониқиш ва хиссий кўтаринкилик бағишлайди. Билишга оид қизиқишлар шахс фаоллигини таъминловчи мотив бўлиб, унинг билиш фаолияти ривожланишига кўмаклашади.

Бошланғич таълимнинг асосий вазифаларидан бири ўқувчиларда китобхонликвоситасидабадиийадабиётгақизиқишнишакллантиришдан 
иборат. Бу мухим масалалардан бири бўлиб, китоблар ва китобхонлик ўқувчиларга таълим-тарбия бериш ва уларни ривожлантиришда катта ахамият касб этади.

Фойдаланилган манбалар:

Педагогика энциклопедия. III жилд. жамоа // Тошкент: «Ўзбекистон миллий энциклопедияси» Давлат илмий нашриёти, 2017. -424 б.

Сафарова Р.Г. ва б. Ўқувчи-ёшларда “оммавий маданият”га қарши курашчанлик кўникмаларини шакллантиришнинг педагогикпсихологик механизмлари.// Монография. - Т.: “Tafakkur qanoti” нашриёти, 2018 йил, 192 бет.

Коменский Я.A. https://ru.wikipedia.org/wiki/Коменский, Ян Aмос

Семёнович

Выготский Л.С. https://ru.wikipedia.org/wiki/ Выготский_Лев_

Тўрақулова О.А. Адабий таълим жараёнида академик лицей ўқувчиларида мутолаа маданиятини ривожлантириш технологияси: педагогика фанлари бўйича фалсафа доктори (Doctor of Philosophy). ...дисс. - Тошкент, 2020. - 174 б. 